\title{
THE RELATIONSHIP OF PREGNANT WOMEN'S KNOWLEDGE WITH ANXIETY IN FACING LABOR DURING THE COVID-19 PANDEMIC
}

\author{
Ni Made Darmiyanti", Vivin Frida Oktaviani \\ Midwifery Department, Health Polytechnic of Kartini Bali. (0361) 720471, Indonesia \\ * Corresponding author \\ E-mail:darmiyanti.md@gmail.com
}

\begin{abstract}
Background: Most people believe that the initial story of the spread of the corona virus or coronavirus disease 2019 abbreviated as Covid-19 began at the end of 2019 when someone contracted the corona virus from animals traded at the Huanan seafood market, Wuhan city, Hubei province, China, and spread to other countries. The purpose of this study was to find out whether there is a relationship between knowledge of pregnant women about Covid-19 and the level of anxiety of pregnant women in facing childbirth during the Covid-19 pandemic in Manggis Village, Bali in 2020.

Methods: This research design uses the correlation method. This study collect the dataa from the third trimester of pregnant women with a population of 63 people and samples that meet the inclusion criteria was 27 people in Manggis Village, Bali in 2020.

Result: The results showed that there was a significant relationship between the knowledge of pregnant women about Covid-19 with the level of anxiety of pregnant women in facing childbirth during the Covid-19 pandemic with a sig. $<0.05$ with a strength level of 0.838 , which means that the relationship is very strong and the relationship is unidirectional. In the statistical test with the Spearman rank, the results showed that there was a significant relationship between knowledge of pregnant women about Covid-19 and the level of anxiety of pregnant women in facing childbirth during the Covid-19 pandemic with a value of sig. $<0.05$ with a relationship strength level of 0.838 which means the relationship very strong and the relationship is unidirectional.
\end{abstract}

Conclusion: Thus, it can be interpreted that if knowledge is increased, anxiety will decrease

Keywords: Anxiety, Covid-19, Knowledge

\section{INTRODUCTION}

Coronaviruses are a large family of viruses that cause mild to moderate upper respiratory tract infections, such as the flu. The incubation period for Covid-19 is not known for certain, but the average symptom appears 2-4 days after the virus first enters the body ${ }^{(2)}$.

For April 27, 2020, the number of cases that were confirmed positive for Covid-19 in Bali was 194 cases, 81 cases recovered and 3 cases died. Karangasem 
Regency itself has 4 positive cases of Covid-19 as of 27 April 2020.

Covid-19 can cause various symptoms, such as fever, cough with mucus, shortness of breath and other symptoms. For people with good immunity, Covid-19 does not cause symptoms or only mild symptoms but in the body there is already a corona virus and can transmit it to others ${ }^{(1)}$.

Pregnancy naturally causes the immune system to decrease, this makes pregnant women more susceptible to infections, including Covid-19 infection. Approaching the time of delivery, the schedule for pregnancy check-ups will be more frequent, this will cause pregnant women to leave the house more often, be out of the house more often and the possibility of contracting Covid-19 will be greater $^{(2)}$.

A case of Covid-19 was reported to a pregnant woman in Boyolali who was tested positive for Covid-19, the patient was exposed to Covid-19 when she was about to have surgery on her pregnancy. When they were about to be treated before surgery, the pregnant woman coughed, then the hospital carried out a swab test to confirm whether or not Covid-19 was infected. From the cases above, pregnant women are very susceptible to being infected with Covid-19, this is what causes pregnant women to be worried about their condition during childbirth if the Covid-19 pandemic has not ended ${ }^{(4)}$.

Pregnancy conditions will cause physical and psychological changes. These physical changes include changes in body shape, swelling of the breasts, frequent urination and changes in appetite. In addition, women who are pregnant will also experience emotional shocks whose intensity is increasing. Sometimes you have strange and irrational desires and habits that are usually accompanied by strong emotions. So that the individual concerned is easily offended, very sensitive and easily disturbed mentally ${ }^{(4)}$.
The purpose of this study was to find out whether there was a relationship between the knowledge of pregnant women about Covid-19 and the anxiety of pregnant women in facing childbirth during the Covid-19 pandemic in Manggis Village in 2020. 


\section{METHODS}

Data collection was carried out online to the respondents, using the social media, by sending a link questionnaires to respondents from September 11 to September 30, 2020. The data processing, analysis and interpretation process done after the data is collected. The population in this study were all pregnant women in the Manggis Village area, with the total number of pregnant women currently being 63 people. Sampling was done by purposive sampling. The inclusion criteria were as follows: 1) Pregnant women who are in August enter the third trimester, 2) Pregnant women or their husbands have smartphones, 3)Pregnant women who can use the WhatsApp application (social media). The number of samples that met the inclusion criteria were 27 people spread over 8 places.

The instrument used to collect data in this study was a list of questions/statements (questionnaires) for both knowledge and level of anxiety given to research subjects. For the measurement of knowledge and level of anxiety, grouped by giving a score. The percentage of correct answers from each sample/respondent calculated using the Arikunto (2010) formula:

$\mathrm{P}=\mathrm{f} / \mathrm{n} \times 100 \%$.

The results of the calculation are then given a score or value, which is as follows: good knowledge if 76-100\% correct answers, sufficient knowledge if $56-75 \%$ correct answers and poor knowledge if less than 55\% correct answers.

Each variable analyzed based on the normal distribution, the data before the parametric statistical test is carried out, the data normality test is carried out using the Shapiro Wilk test. The test results at the error level > 0.05 means the data is normally distributed, data processing is assisted by a computer with statistical tests using Spearman Rank

\section{RESULT}

The research subjects used in this study were pregnant women in the third trimester in August, amounting to 27 people in the Pustu Manggis area. The following is a pie chart of the characteristics of research subjects based on age

Diagram 1. Characteristics of research subjects by age

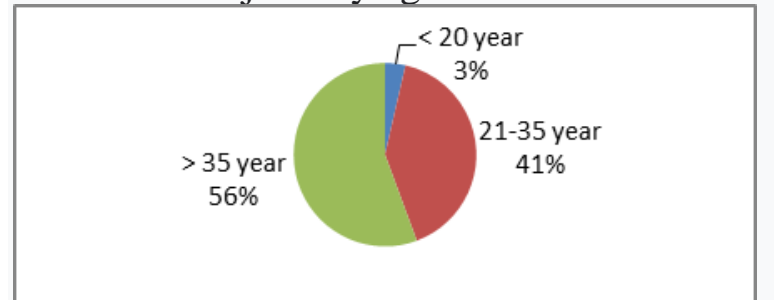

Based on diagram 1, information is obtained that of the 27 research subjects most of them $(55.6 \%)$ are over 35 years old, almost half $(40.7 \%)$ are $20-35$ years old and only a small percentage $(3.6 \%)$ aged less than 20 years. This reflects that the research subjects are mostly of healthy reproductive age.

Diagram 5.2. Frequency Distribution of Research Subject Characteristics Based on work

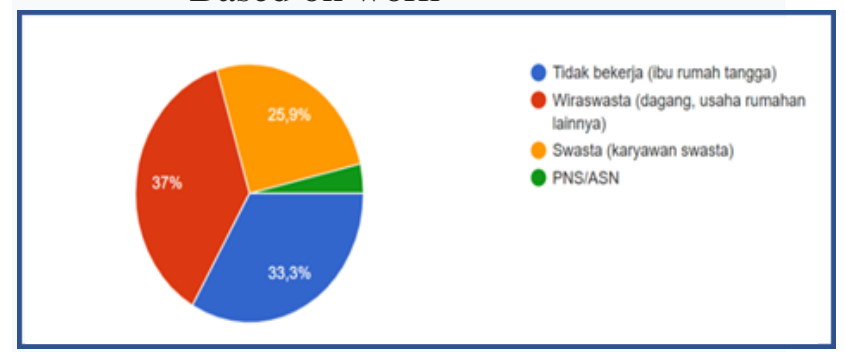

In diagram 2 above, information is obtained that $33.3 \%$ of respondents are unemployed, $25.9 \%$ are private employees, $37 \%$ are selfemployed and only $3.8 \%$ work as civil servants.

Diagram 3. Frequency Distribution of Research Subject Characteristics Based on Education

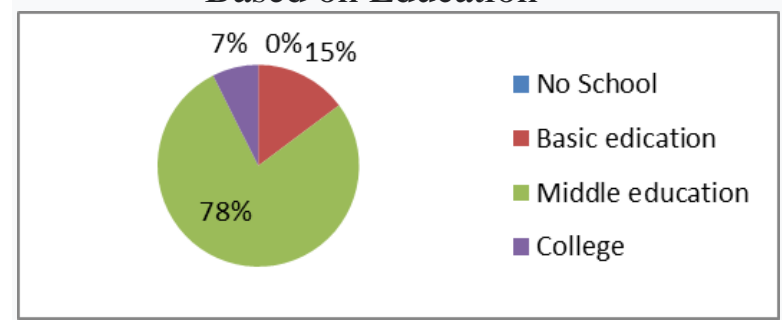


In diagram 3 above, information is obtained that most of the research subjects $(77.8 \%)$ have high school education, only a small proportion have basic education and tertiary education, respectively $14.8 \%$ and $7.4 \%$.

The measurement of knowledge of pregnant women as research subjects by researchers assisted by research assistants is carried out online by providing a knowledge questionnaire link consisting of 10 questions about Covid-19, the following is a diagram of knowledge.

Univariate analysis : Frequency Distribution of Pregnant Women's Knowledge About Covid-19

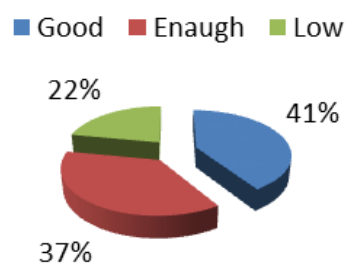

Based on the univariate analysis above, it was found that almost half $(41 \%)$ of the knowledge of the research subjects were in the good category, most (37\%) had sufficient knowledge and only a small portion (22\%) had less knowledge about Covid-19

The following is data on the level of anxiety of pregnant women in facing childbirth during the Covid-19 pandemic.

Univariate analysis: Distribution of the Anxiety Frequency of Pregnant Women in Facing Childbirth during the Covid-19 Pandemic

Heavy, 0 Medium,

Based on diagram 5.5 above, information is obtained that of the 27 research subjects, most $(89 \%)$ have an anxiety level in the light category, only a small percentage (11\%) have an anxiety level in the medium category, and none have an anxiety level in the heavy category.

The relationship between knowledge of pregnant women about Covid19 and anxiety in dealing with childbirth during the Covid-19 pandemic can be seen in the following table 1:

Table 1. The knowledge level and level of anxiety

\begin{tabular}{cccccc}
\hline $\mathbf{N}$ & Category & \multicolumn{2}{c}{ Knowledge } & \multicolumn{2}{c}{ Anxiety } \\
\cline { 3 - 6 } $\mathbf{0}$ & & $\mathbf{F}$ & $\mathbf{\%}$ & $\mathbf{F}$ & $\mathbf{\%}$ \\
$\mathbf{1}$ & Good/light & 11 & 40 & 24 & 88 \\
$\mathbf{2}$ & Enough/medium & 10 & 37 & 3 & 12 \\
$\mathbf{3}$ & Low/heavy & 6 & 22 & 0 & 0 \\
& Total & $\mathbf{2 7}$ & $\mathbf{1 0 0}$ & $\mathbf{2 7}$ & $\mathbf{1 0 0}$ \\
\hline
\end{tabular}

In table 1 above, information is obtained that the results of descriptive analysis between the knowledge of pregnant women about Covid-19 and the level of anxiety of pregnant women in facing childbirth during the Covid-19 pandemic, that almost half (40\%) of pregnant women's knowledge about Covid-19 is in the good category, while most of the anxiety levels of pregnant women in facing childbirth during the Covid-19 pandemic were in the mild category. For knowledge in the less category only a small part (22\%), while for the level of anxiety in the severe category there is none $(0 \%)$.

To see the relationship between knowledge and anxiety levels of pregnant women in dealing with childbirth during the Covid-19 pandemic using the Rank Spearman statistical test, with the following results

Table 2. Rank Spearman Test Results

\begin{tabular}{ccccc}
\hline Var 1 & n & Sig & r & Var 2 \\
\hline Knowledge & 27 & 0.001 & 1.000 & Anxiety \\
\hline
\end{tabular}

In tables 1 and 2 above, information is obtained that there is a significant relationship between knowledge of pregnant women about Covid-19 and the level of anxiety of pregnant women in facing 
childbirth during the Covid-19 pandemic with a value of sig. $<0.05$ with a strength level of 0.838 which means the relationship very strong and the relationship is unidirectional, thus it can be interpreted that if knowledge is increased, anxiety will decrease.

\section{DISSCUSION}

According to Notoatmodjo, 2003

knowledge is the result of "knowing" and this occurs after people have sensed a certain object. Knowledge or cognitive is a very important domain for the formation of one's actions. Knowledge can generally be obtained from information submitted by parents, teachers and the mass media. Education is very closely related to knowledge, education is one of the basic human needs that is indispensable for selfdevelopment. The higher a person's level of education, the easier it will be to receive and develop knowledge and technology ${ }^{(5)}$.

This study is in line with research conducted by Nurtini, NM, et al (2020) regarding the relationship between the level of knowledge and the anxiety of pregnant women during the COVID 19 pandemic, the result of which is that there is a relationship between the level of knowledge and anxiety of pregnant women during the COVID 19 pandemic ${ }^{(6)}$.

Anxiety is a feeling that is general in nature, where a person feels afraid or loses self-confidence that is not clear or manifest ${ }^{(7)}$. Most of the research subjects experienced a level of anxiety in the mild category related to the level of education, most of which were high school/equivalent, this is in accordance with research conducted by Nur S and Restu A, 2014 concerning the relationship between education level and anxiety level of women aged 40-50 years in the face of menopause with the results of 101 respondents obtained as many as $62.3 \%$ of respondents have low education (basic) with 95\% level of anxiety in the severe category, statistically using the Spearman rank test obtained $\mathrm{p}$ value $<0.05$ which indicates there is a relationship between education and the level of anxiety of women aged 40-50 years in the face of menopause ${ }^{(8)}$.

According to the researcher's assumption, until now, some people still think that Covid-19 is just a political conspiracy, or that it doesn't exist or is not real so that people don't believe in the existence of the Covid-19 pandemic, this has resulted in the public's concern and attention on this virus not being serious ${ }^{(9)}$.

Research conducted by Ervina (2020) regarding the relationship between the level of anxiety and knowledge of pregnant women in the third trimester with readiness to face childbirth during the COVID-19 pandemic conducted at the Benowo Health Center is in line with the results of this study, namely there is a relationship between the level of knowledge and the level of anxiety of pregnant women in the third trimester. in dealing with childbirth during the COVID-19 pandemic ${ }^{(10)}$.

Research that is in line with this research is the research conducted by Reny and Yanti F (2020) about the relationship between the level of knowledge and the anxiety of pregnant women about ante natal care during the COVID-19 pandemic, with the results that there is a relationship between the level of knowledge and the level of anxiety of pregnant women about ante natal care. during the COVID-19 pandemic ${ }^{(11)}$.

An accordance with research conducted by Martinus AP (2020) on government policies in efforts to prevent the COVID-19 outbreak, which also promises the researcher's assumption is that there is a relationship between the knowledge of pregnant women about Covid-19 and the anxiety of pregnant women in dealing with childbirth during the Covid-19 pandemic, because Covid-19 is a new epidemic that has hit the world, all elements of the central and regional governments and various nongovernmental organizations. With very serious efforts to control the transmission of this infection, all the capabilities of the government and elements of the community are mobilized so that the public is alert and participates in efforts controlling the 
transmission of Covid-19, so that this causes information about Covid-19 to spread quickly in the community which can automatically increase public knowledge about Covid-19. Until now, there have been no pregnant women in Manggis Village who have been confirmed to be infected with Covid-19, this has also caused public anxiety, especially pregnant women, regarding childbirth during the Covid-19 pandemic to be in the moderate category ${ }^{(12)}$.

\section{CONCLUSION}

The knowledge of pregnant women about Covid-19 is almost entirely in the good category. The level of anxiety of pregnant women in facing childbirth during the Covid19 pandemic was mostly in the mild category. There is a significant, very strong and unidirectional relationship between the knowledge of pregnant women about Covid19 and the level of anxiety of pregnant women in facing childbirth during the Covid19 pandemic.

\section{ACKNOWLEDGMENT}

The writing team would like to thank God Almighty for giving a bless so that this research can be completed on time. We also would like to thank the Kartini Bali Foundation which has funded this research, the Director of Poltekkes Kartini Bali who has provided the opportunity to conduct research, and LPPM which has become a facilitator for the research process.

\section{REFERENCES}

1. Lisa, 2018. Tingkat Kecemasan Mahasiswa Keperawatan Dalam Menghadapi Ujian Berbasis Komputer Based Test. Jurnal Sistem Kesehatan. Unpad. Pp: 56-58, 63-65.

2. Khoirul, 2013. Faktor-faktor yang Mempengaruhi Kecemasan Mahasiswa untuk Berbicara di Depan Umum .Jurnal Kesehatan Masyarakat. Undip. Pp : 76-77, 87-90, 91-95
3. Rothan, H. A., \& Byrareddy, S. N. (2020). The epidemeology and pathogensis of coronavirus (Covid-19) outbreak. Journal of Autoimmunity, 109, 1-4.

4. Fehr, A.R (2015). Coronavirus: An Overview of Their Replication and Pathogenesis. Methods Mol Biol.

5. Notoatmodjo, S. (2005). Metodelogi Penelitian Kesehatan. Pp : 129-135

6. Nurtini, et al 2010. Hubungan Tingkat Pengetahuan dengan Kecemasan Ibu Hamil di Masa Pandemi Covid 19. Jurnal Riset Kesehatan Nasional. Pp: 94-100

7. Sri A. 2015. Hubungan Tingkat Pengetahuan Tentang Preoperatif Dengan Tingkat Kecemasan Pada Klien Preoperatif Katarak. Jurnal Midwifery Zigot. Universitas Jember. Pp: 67-69, 7173

8. Nur S, Restu A. 2014. Hubungan Tingkat Pendidikan Dengan Tingkat Kecemasan Wanita Usia 40-50 tahun Dalam Menghadapi Menopause. Jurnal Komunikasi Kesehatan. Pp: 54-56, 59-60

9. Dinkes Prov.Bali, 2019. Laporan Kasus Positif Covid-19 per 27 April 2020

10. Renny, Yanti F. 2020. Hubungan Tingkat Kecemasan dan Pengetahuan Ibu Hamil Tentang Antenatal Care Saat Pandemi Covid 19. Prosiding Seminar Nasional.

11. WHO, 2020. The Number of Positive Cases Covid-19 in The World

12. Huang et al, 2020. Wellness. Journalpress.Id 